\title{
Estrogen receptor-related receptors in the killifish Fundulus heteroclitus: diversity, expression, and estrogen responsiveness
}

\author{
A M Tarrant, S R Greytak ${ }^{\mathbf{1}}$, G V Callard ${ }^{\mathbf{1}}$ and M E Hahn \\ Biology Department, Woods Hole Oceanographic Institution, Woods Hole, Massachusetts 02543, USA \\ ${ }^{1}$ Department of Biology, Boston University, Boston Massachusetts 02215, USA \\ (Requests for offprints should be addressed to A M Tarrant; Email: atarrant@ whoi.edu)
}

\begin{abstract}
The estrogen receptor-related receptors (ERRs) are a group of nuclear receptors that were originally identified on the basis of sequence similarity to the estrogen receptors. The three mammalian ERR genes have been implicated in diverse physiological processes ranging from placental development to maintenance of bone density, but the diversity, function, and regulation of ERRs in non-mammalian species are not well understood. In this study, we report the cloning of four ERR cDNAs from the Atlantic killifish, Fundulus heteroclitus, along with adult tissue expression and estrogen responsiveness. Phylogenetic analysis indicates that $F$. heteroclitus (Fh)ERR $\alpha$ is an ortholog of the single ERR $\alpha$ identified in mammals, pufferfish, and zebrafish. FhERR $\beta$ a and FhERR $\beta b$ are co-orthologs of the mammalian ERR $\beta$. Phylogenetic placement of the fourth killifish ERR gene, tentatively identified as FhERR $\gamma b$, is less clear. The four ERRs showed distinct, partially overlapping mRNA expression patterns in adult tissues. FhERR $\alpha$ was broadly expressed. FhERRßa was expressed at apparently low levels in eye, brain, and ovary. FhERRßb was expressed more broadly in liver, gonad, eye, brain, and kidney. FhERR $\gamma b$ was expressed in multiple tissues including gill, heart, kidney, and eye. Distinct expression patterns of FhERR $\beta a$ and FhERR $\beta b$ are consistent with subfunctionalization of the ERR $\beta$ paralogs. Induction of ERR $\alpha$ mRNA by exogenous estrogen exposure has been reported in some mammalian tissues. In adult male killifish, ERR expression did not significantly change following estradiol injection, but showed a trend toward a slight induction (three- to five-fold) of ERR $\alpha$ expression in heart. In a second, more targeted experiment, expression of ERR $\alpha$ in adult female killifish was downregulated $2 \cdot 5$-fold in the heart following estradiol injection. In summary, our results indicate that killifish contain additional ERR genes relative to mammals, including ERR $\beta$ paralogs. In addition, regulation of ERR $\alpha$ expression in killifish apparently differs from regulation in mammals. Together, these features may facilitate determination of both conserved and specialized ERR gene functions.
\end{abstract}

Journal of Molecular Endocrinology (2006) 37, 105-120

\section{Introduction}

The estrogen receptor-related receptors (ERRs) are members of the nuclear receptor superfamily of transcription factors (Giguere et al. 1988). Three ERR genes have been identified in mammals, ERR $\alpha$ (NR3B1), ERR $\beta$ (NR3B2), and ERR $\gamma$ (NR3B3) (Giguere et al. 1988, Chen et al. 1999, Hong et al. 1999, Heard et al. 2000). ERRs and estrogen receptors (ERs) have overlapping affinities for co-activators and DNA-binding sites, but differ markedly in ligand binding and activation (Vanacker et al. $1999 a, b$, Giguere 2002). Unlike ERs, ERRs do not bind estradiol, and have been reported to be either constitutively active (Hong et al. 1999, Xie et al. 1999, Greschik et al. 2002) or activated by an unidentified ligand (Vanacker et al. 1999b). While high-affinity ERR agonists have not been identified, some ER ligands, including 4-hydroxytamoxifen and diethylstilbestrol, can antagonize ERR activity (Coward et al. 2001, Tremblay et al. $2001 a, b)$.

The functions and target genes of ERRs are not yet well understood. ERR $\alpha$ helps to regulate bone growth and maintenance by binding to the osteopontin promoter, a gene target that is shared with ER $\alpha$ (Bonnelye et al. 1997b, 2001, Vanacker et al. 1999a). $\mathrm{ERR} \alpha$ has also been shown to repress activity of PPAR $\gamma$ co-activator $1 \alpha$ (PGC- $1 \alpha)$, a co-activator that interacts with PPARs (peroxisome proliferator-activated receptors) to regulate gluconeogenesis and adaptive thermogenesis (Ichida et al. 2002). ERR $\alpha$-null mutant mice are essentially normal with reduced body weight and peripheral fat deposits, which supports the hypothesis that ERR $\alpha$ helps to regulate energetic metabolism and fat storage (Luo et al. 2003). In contrast to the mild ERR $\alpha$ knockout phenotype, ERRß-null mutants die during development due to defects in placental formation (Luo et al. 1997). 
ERR $\beta$-null mutants rescued from embryonic lethality exhibit behavioral abnormalities and reduced numbers of germline cells (Mitsunaga et al. 2004). The role of ERR $\gamma$ has not been elucidated through knockout experiments, but high expression has been noted in differentiating neural tissues (Hermans-Borgmeyer et al. 2000). Other proposed target genes for ERRs include lactoferrin, aromatase, small heterodimer partner, endothelial nitric oxide synthase, SULT2A1, and thyroid hormone receptor- $\alpha$ (Yang et al. 1996, Vanacker et al. 1998, Zhang \& Teng 2000, Sanyal et al. 2002, Sumi \& Ignarro 2003, Seely et al. 2005).

In mice, ERR $\alpha$ and ERR $\gamma$ are broadly expressed in adult and embryonic tissues (Bonnelye et al. 1997a, Shigeta et al. 1997, Heard et al. 2000, HermansBorgmeyer et al. 2000). In contrast, ERR $\beta$ has more limited expression, most notably in a subset of placental cells during early embryonic development and in developing germ cells (Pettersson et al. 1996, Luo et al. 1997, Mitsunaga et al. 2004). In the adult, ERR $\beta$ is expressed at low levels in a few tissues including kidney, heart, testis, hypothalamus, hippocampus, cerebellum, and prostate (Giguere et al. 1988, Pettersson et al. 1996). ERR $\alpha$ expression can be upregulated by estrogen exposure in some mammalian tissues (Shi et al. 1997, Shigeta et al. 1997, Liu et al. 2003), but regulation of ERR expression is not well understood.

Examination of teleost genomic databases has revealed that fishes contain additional diversity of ERR genes as compared with mammals: six ERR genes have been identified in the Japanese pufferfish Takifugu rubripes ('fugu'), five in the spotted green pufferfish Tetraodon nigroviridis ('tetraodon'), and five in the zebrafish Danio rerio (Bardet et al. 2002, Bertrand et al. 2004). A genome duplication within the teleost lineage (Amores et al. 1998, Taylor et al. 2001, Christoffels et al. 2004, Jaillon et al. 2004, Postlethwait et al. 2004) may account for some of the additional ERR diversity, but it has also been suggested that the ERR $\delta$ identified in zebrafish and fugu has been secondarily lost from mammals and tetraodon (Bardet et al. 2002). Additional diversity of ERR genes within the teleost lineage is of evolutionary interest, but also provides an opportunity to gain mechanistic insight into mammalian ERR genes. In particular, the duplication, degeneration, complementation hypothesis predicts that the multiple functions of a gene (e.g. a mammalian ERR) may be partitioned between duplicated co-orthologs (Force et al. 1999, Lynch \& Force 2000).

The few published studies of ERR function in fishes and invertebrates have provided insight into evolutionary biology and novel aspects of ERR function. For example, in situ hybridization showed that ERRs are developmentally expressed in a segmented pattern in both the amphioxus (single ERR) and the zebrafish $(\mathrm{ERR} \alpha, \mathrm{ERR} \beta \mathrm{b}$, and ERR $\gamma \mathrm{a})$ hindbrain, which indicates that a structure similar to a segmented hindbrain predated the divergence of invertebrates and vertebrates (Bardet et al. 2005b). Knockdown of ERR $\alpha$ expression using morpholino antisense oligonucleotides in zebrafish indicated a novel role for ERR in regulating morphogenic movement during gastrulation (Bardet et al. 2005a). ERRs of zebrafish and human are similar with respect to ligand binding and transactivation (Bardet et al. 2004); however, further investigation is needed to understand ERR signaling in teleosts. For example, ERR expression patterns have not been described in adults of any teleost species and regulation of teleost ERR expression (e.g. in response to estradiol exposure) has not been described.

In this study, we report the cloning, adult tissueexpression patterns and estrogen responsiveness of ERR cDNAs in the Atlantic killifish, Fundulus heteroclitus. F. heteroclitus has been used as a model species for several recent studies of endocrine disruption. In particular, laboratory and natural populations exposed to environmental contaminants show altered levels of sex steroids (Dube \& MacLatchy 2001, Hewitt et al. 2002, MacLatchy et al. 2003, Boudreau et al. 2004, Greytak et al. 2005), thyroid hormones (Zhou et al. 2000, Carletta et al. 2002), and aromatase mRNA (Greytak et al. 2005). Given the cross-talk between mammalian ERs and ERRs (Vanacker et al. 1999a, Giguere 2002), and the hypothesized regulatory role of ERR $\alpha$ in aromatase and thyroid receptor expression (Vanacker et al. 1998, Yang et al. 1998), elucidation of ERR signaling may provide insight into endocrine regulation and disruption in this model species. Specific objectives of this study were: (1) to determine whether $F$. heteroclitus contained duplicated co-orthologs of any mammalian ERR gene, which could provide insight into gene function, (2) to compare adult tissue expression patterns of killifish ERR cDNAs with expression patterns reported for mammalian ERRs, and (3) to determine whether estradiol exposure affects killifish ERR cDNA expression, especially the expression of ERR $\alpha$.

\section{Materials and methods}

\section{Animals and RNA isolation}

For cloning of ERR and determination of tissue-specific expression patterns, F. heteroclitus (Atlantic killifish or mummichog) were trapped in salt marshes surrounding Scorton Creek on Cape Cod, MA, USA in May and June 2003. Fish were reproductively active, with mature eggs visible in the ovaries. Three adult male fish and three adult female fish were anesthetized with MS-222 and killed via cervical transection. Liver, gonad, brain, eye, kidney, gill, gut, heart, and spleen were dissected and pooled for the three fish of a given sex. Total RNA 
was isolated from tissues using RNA STAT-60 (Tel-Test, Inc.). A negative control consisted of a sham RNA extraction with no tissue added.

Two experiments were conducted to determine the effects of estradiol exposure on ERR mRNA transcript expression. In both the experiments, reproductively regressed adult $F$. heteroclitus were collected from Scorton Creek and injected intra-peritoneally with estradiol $(5 \mu \mathrm{g} / \mathrm{g}$ body weight, as a $1 \mu \mathrm{g} / \mu \mathrm{l}$ solution in sesame oil) or with a vehicle control (sesame oil). Both concentration and method of exposure are predicted to produce a high spike in plasma estradiol concentration that is cleared rapidly (Pankhurst et al. 1985) and a robust induction of vitellogenesis in male fish (Pait \& Nelson 2003).

In the first experiment, male $F$. heteroclitus were injected in November 2003 and sacrificed after 2 or 5 days. The organs were immediately flash-frozen, and the total RNA was extracted subsequently from organs of individual fish using Tri-reagent (Sigma). Thirteen fish were injected in total (6 with estradiol and 7 with vehicle), giving a sample size of 3-4 fish per time point within a treatment.

In the second experiment, adult female $F$. heteroclitus were injected in January 2005 and sacrificed after 2 days. The organs were flash-frozen as in the previous experiment and total RNA was extracted from organs of individual fish with STAT-60. Twenty five fish were injected in total $(n=12$, estradiol treatment; $n=13$, vehicle control).

\section{Reverse transcriptase (RT)-PCR}

cDNA was synthesized from $3 \mu \mathrm{g}$ total RNA using random hexamers and the Omniscript cDNA Synthesis Kit (Qiagen). Degenerate oligonucleotide primers, ERRf1 and ERRr1, were designed based on highly conserved regions of the fugu-predicted ERR genes (Table 1). PCRs with these degenerate primers resulted in two different cDNAs (441 bp F. heteroclitus (Fh)ERR $\alpha$ and $432 \mathrm{bp}$ FhERRßa) when used with Advantage2 Polymerase (BD Biosciences Clontech) with the following cycling conditions in a Perkin-Elmer GeneAmp 2400 thermocycler: $95^{\circ} \mathrm{C} / 60 \mathrm{~s}\left(95^{\circ} \mathrm{C} / 30 \mathrm{~s}\right.$, $65^{\circ} \mathrm{C} / 45 \mathrm{~s}, 68^{\circ} \mathrm{C} / 45 \mathrm{~s}$ ) for 35 cycles, $68^{\circ} \mathrm{C} / 60 \mathrm{~s}$. Additional degenerate primers were targeted toward other ERR genes predicted from the fugu genome. These reactions were conducted using AmpliTaq Gold Polymerase (Applied Biosystems, Framingham, MA, USA). A $398 \mathrm{bp}$ cDNA fragment (FhERR $\beta$ b) was amplified using ERRf2 and ERRr1 under the following conditions: $94^{\circ} \mathrm{C} / 5 \mathrm{~min}\left(94^{\circ} \mathrm{C} / 15 \mathrm{~s}, 62 \cdot 5^{\circ} \mathrm{C} / 15 \mathrm{~s}\right.$, $\left.72{ }^{\circ} \mathrm{C} / 30 \mathrm{~s}\right), 72^{\circ} \mathrm{C} / 5 \mathrm{~min}$, followed by $\left(94^{\circ} \mathrm{C} / 15 \mathrm{~s}\right.$, $62{ }^{\circ} \mathrm{C} / 15 \mathrm{~s}, 72{ }^{\circ} \mathrm{C} / 30 \mathrm{~s}$ ) for 10 cycles, $72{ }^{\circ} \mathrm{C} / 5 \mathrm{~min}$. ERRf3 and ERRr1 amplified a $324 \mathrm{bp}$ fragment (FhERR $\gamma$ b) at $95^{\circ} \mathrm{C} / 10 \mathrm{~min}\left(94^{\circ} \mathrm{C} / 15 \mathrm{~s}, 63.5{ }^{\circ} \mathrm{C}\right.$ / $15 \mathrm{~s}, 72{ }^{\circ} \mathrm{C} / 30 \mathrm{~s}$ ) for 35 cycles, $72{ }^{\circ} \mathrm{C} / 10 \mathrm{~min}$.

\section{Rapid amplification of cDNA ends (RACE) and amplification of full-length PCR products}

$5^{\prime}-/ 3^{\prime}$-RACE reactions were performed using a SMART RACE cDNA amplification kit (BD Biosciences Clontech). Briefly, adapter-ligated, oligo(dT)-primed cDNA was produced from brain or liver total RNA. Genespecific primers were used with adapter primers in PCR. To most RACE PCR, 5\% dimethylsulfoxide (DMSO) was added. Touchdown PCRs cycling conditions were used according to the manufacturer's instructions with primers shown in Table 1. For FhERR $\alpha 5^{\prime}$-RACE, primer ERRAr1 and nested primer ERRAr2 were used to generate a partial $5^{\prime}$-RACE product. To obtain the $5^{\prime}$ end of FhERR $\alpha$, primer ERRAr3 was used as a nested primer. For FhERR $\alpha 3^{\prime}$-RACE, primer ERRAf1 was used. For FhERR $\beta$ a 5'-RACE, a partial 5'-RACE product was obtained using primer ERRB1r1. To obtain a complete $5^{\prime}$ sequence, additional fragments were amplified using nested primers ERRB1r2 and ERRB1r3. For FhERR $\beta$ a 3'-RACE and FhERR $\beta b$ 5'-RACE, primers ERRB1f1 and ERRB2r1 were used, respectively, in two rounds of PCR with nested adapter primers. For FhERR $\beta$ b 3'-RACE, primer ERRB2f1 and nested primer ERRB2f2 were used. For FhERR $\gamma \mathrm{b}$ 5'-RACE, primer ERRGr1 and nested primer ERRGr2 were used. For FhERR $\gamma b$ 3'-RACE, primer ERRGf1 and nested primer ERRGf2 were used.

Once full-length RACE products were obtained, additional gene-specific primers (Table 1) were designed within the untranslated regions to amplify full-length PCR products for each gene. All full-length products were amplified using Advantage2 Polymerase with 5\% DMSO added to the reactions. FhERR $\alpha$, FhERR $\beta b$, and FhERR $\gamma b$ were amplified from cDNA made from brain total RNA using the following cycling conditions: $94^{\circ} \mathrm{C} / 1 \mathrm{~min}, 35-37$ cycles of $\left(94^{\circ} \mathrm{C} / \mathrm{s}\right.$, $\left.65{ }^{\circ} \mathrm{C} / 10 \mathrm{~s}, 68^{\circ} \mathrm{C} / 2 \mathrm{~min}\right), 72^{\circ} \mathrm{C} / 7 \mathrm{~min}$. FhERR $\beta$ a was amplified from cDNA made from brain poly-A + RNA using the following cycling conditions: $94^{\circ} \mathrm{C} / 1 \mathrm{~min}, 40$ cycles of $\left(94^{\circ} \mathrm{C} / \mathrm{s}, 64{ }^{\circ} \mathrm{C} / 10 \mathrm{~s}, 69^{\circ} \mathrm{C} / 2 \mathrm{~min}\right), 72^{\circ} \mathrm{C} /$ $7 \mathrm{~min}$. During analysis of $5^{\prime}$-RACE products and fulllength cDNA clones for FhERR $\alpha$, an apparent frame shift was noted in the sequence. When these sequences were aligned with the other fish ERR $\alpha$ sequences, it appeared that the FhERR $\alpha$ clones might be missing a section coding for 16 amino acid residues. Using specific primers, we amplified a $300 \mathrm{bp}$ product that overlapped previous sequences and contained an additional $56 \mathrm{bp}$ in the frame shift region. The $300 \mathrm{bp}$ product and the $56 \mathrm{bp}$ insert had 68 and $80 \%$ GC content respectively. The high GC content of this region is likely to have resulted in the secondary structure leading to errors in RT-PCR. The complete predicted cDNA sequence is thus a composite of full-length clones with the $56 \mathrm{bp}$ region inserted; the 
Table 1 Oligonucleotide sequences of primers. In degenerate primers $\mathrm{S}=\mathrm{C}$ or $\mathrm{G}, \mathrm{W}=\mathrm{A}$ or $\mathrm{T}, \mathrm{R}=\mathrm{A}$ or $\mathrm{G}$

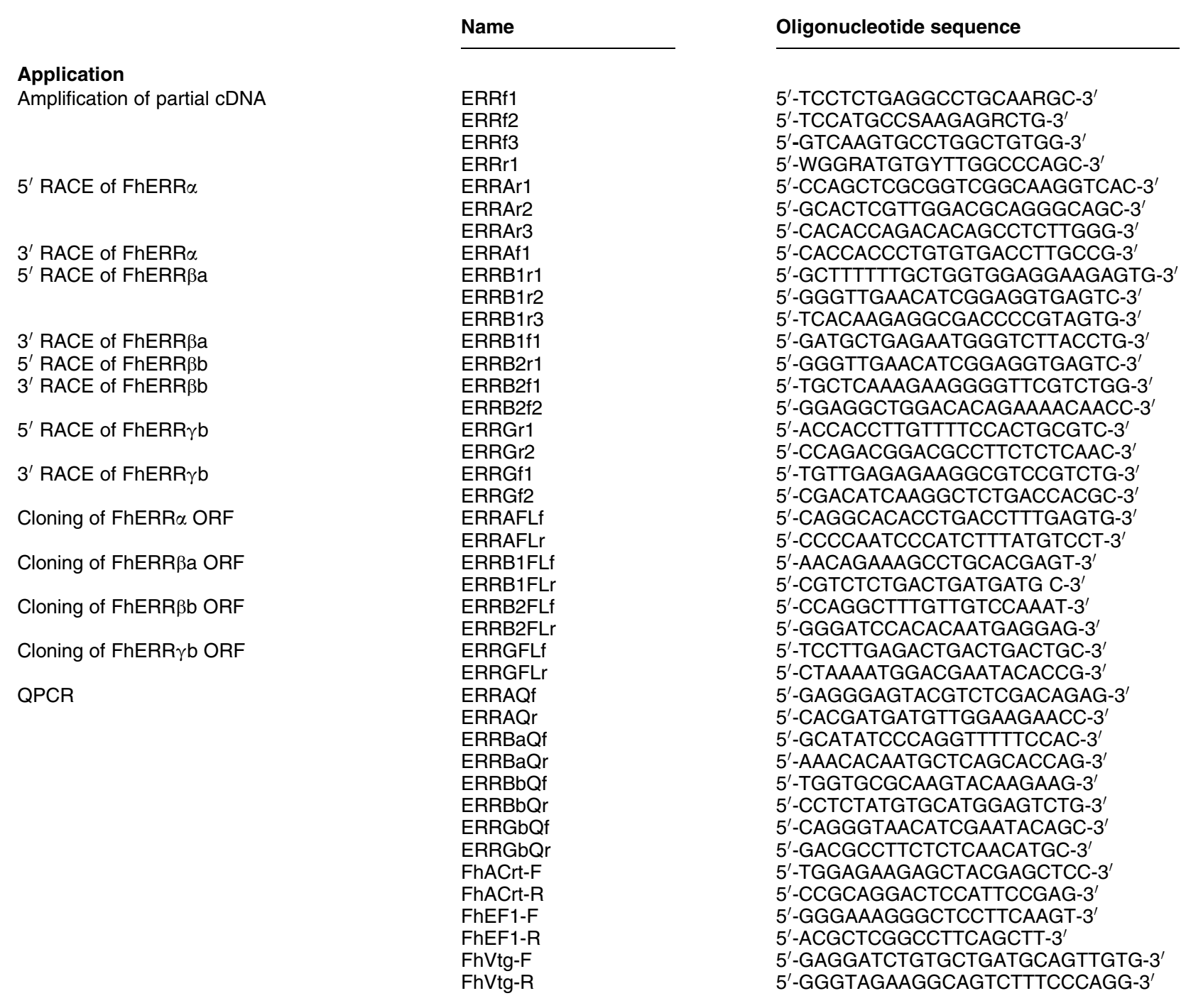

ORF, open reading frame; QPCR, quantitative real-time PCR

location of the insert is marked in Fig. 1. The insert is well conserved among fishes (not shown) but not between fishes and mammals.

\section{Cloning and sequencing}

All PCR products were cloned into pGEM-T Easy (Promega). PCR products were sequenced by the University of Maine DNA Sequencing Facility (Orono, ME, USA) or at the Bay Paul Center Sequencing Facility (Marine Biological Laboratory, Woods Hole, MA, USA). Both strands from multiple clones were sequenced to ensure accuracy. DNA sequences were analyzed, assembled, and translated using the Wisconsin Package
(GCG, Accelrys, Burlington, MA, USA) and Bioedit Sequence Alignment Editor software (Hall 1999).

\section{Phylogenetic analysis}

F. heteroclitus ERR-deduced amino acid sequences were aligned with previously reported ERR sequences from fishes, mammals, and Drosophila melanogaster using Clustal X 1.81 with default parameters (for accession numbers see Table 2). Gaps and the highly variable A/B domain were excluded from phylogenetic analysis. The aligned amino acid sequences were used to create phylogenetic trees using maximum parsimony and distance (minimum evolution) criteria with 


\begin{tabular}{|c|c|c|}
\hline FhERR $\alpha$ & & $\mid \begin{array}{l}|\cdots| \\
\text { MSSRERRSD-- }\end{array}$ \\
\hline HsERR $\alpha$ & & 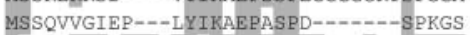 \\
\hline FhERRßa & & MPTDDRHLPSSCGSYVKTEPSSPSSSLVDTGSHHSP \\
\hline EhERRßb & MDISELCLPDPLSYHNQALLSKSLERFLSPMATLETSHFWLLNR & MMAADERHLPSSCGSYIKTEPSSPSS-VIDTVSHHSP \\
\hline HSERRB & & MSSDDRHLGSSCGSFIKTEPSSPSS-GIDALSHHSP \\
\hline FhERRy & & MS--VRGLDPACPTSIKREPSSPSPSSQGDVSPAQP \\
\hline HsERRy & & MSNKDRHIDSSCSSFIKTEPSSPAS-LTDSVNHHSE \\
\hline
\end{tabular}

\section{FhERR $\alpha$}

HSERR $\alpha$

FhERRßa

FhERRßb

HSERR $\beta$

FhERRY

HSERRY

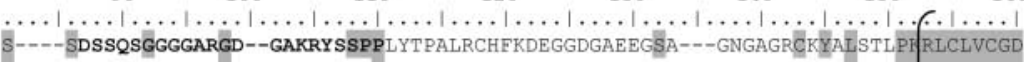
S----ETETEPPVALAPG--------PAPTRCLPGHKEEEDGEGAGPGEQ---GGG----KLVLSSLPI RLCLVCGD S---GNSDASGGYVNGTG--GRSHALDSPPMENPG-MLGGGSACLRRYEECSGSMTDDSPIRCEYMLNAI PH RLCLVCGD S---GNSDASGGYVSTMN--SHSNGODSPPMFTPG-GLGAG-SCRKRYDDCSSTIMEDSSIKCEYMLNSLPH RLCLVCGD S---GSSDASGGFGLALG--THANGLDSPPMFAGA-GLGGT-PCRKSYEDCASGIMEDSAIKCEYMLNAIPI RLCLVCGD SPGSSSSDTNSSYGPLTKGLAHNNGLESPSLCGHTAGLANNGGANRRFGE-----DEGQVKCEFMLGTVA) RVCLVCGD G---GSSDASGSYSSTMN--GHQNGLDSPPLYPSAPILGGSGPVRKLYDDCSSTIVEDPQTKCEYMLNSMPI (RLCLVCGD

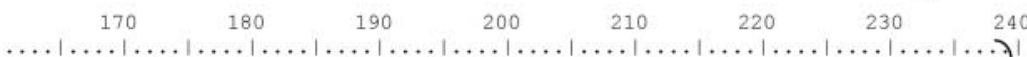

FhERR $\alpha$ HsERR $\alpha$ EhERRßa FhERRßb HSERR $\beta$ FhERRY HSERRY VASGYHYGVASCEACKAFFKRTIQGNIEYSCPASNECEITKRRRKACQACRFTKCLKVGMLKEGVRLDRVRGGRQKYKA VASGYHYGVASCEACKAEFKRTIQGSIEYSCPASNECEITKRRRKACQACRETKCLRVGMLKEGVRLDRVRGGRQKYKRR IASGYHYGVASCEACKAFFKRTIQGNIEYSCPATNECEITKRRRKSCQACREMKCLKVGMLKEGVRLDRVRGGRQKYKAR IASGYHYGVASCEACKAFFKRTIQGNIEYSCPATNECEITKRRRKSCQACRFMKCLKVGMLKEGVRLDRVRGGRQKYKAR IASGYHYGVASCEACKAFFKRTIQGNIEYSCPATNECEITKRRRKSCQACRFMKCLKVGMLKEGVRLDRVRGGRQKYKAR VASGYHYGVASCEACKAEFKRTIQGNIEYSCPASNECEITKRRRKSCQACRFLKCLAVGMLREGVRLDRVRGGRQKYKAR IASGYHYGVASCEACKAFFKRTIQGNIEYSCPATNECEITKRRRKSCQACREMKCLKVVGMLKEGVRLDRVRGGRQKYKBR

$\begin{array}{rrrrrrrr}250 & 260 & 270 & \downarrow & 280 & 290 & 300 & 310\end{array}$

FhERR $\alpha$ $\ldots|\ldots| \ldots|\ldots| \ldots|\ldots| \ldots|\ldots| \ldots|\ldots| \ldots|\ldots| \ldots|\ldots| \ldots|\ldots| \ldots|\ldots| \ldots \mid$ PEVEN----ATYQSAPLSLTKESEKGSS----NIIVSHLLVAEPEKLFAMPDPLQPDTAQRTLTTLCDLADRELVVIIGW PEVDPLPFPGPEPAGPLAVAGGPRKTAAPV--NALVSHLLVVEPEKLYAMPDPAGPDGHLPAVATLCDLFDREIVVTISW FhERRßa LDAEN----GSYLGLTLPPPAKKPLT------KIVSHLLVVEPEKI YAMPDPTMPDGDIKALTTLCDLADRELVVIIGW
FhERRßb LDTEN---NNPLGLTLPPPTKKPLT-----KIVSHLLVAEPEKIYAMPDPTMPESDIKALTTLCDLADRELVVIIGW HSERR $\beta$ LDSES----SPYLSLQISPPAKKPLT------KIVSYLIVAEPDKLYAMPPPGMPEGDIKALTTLCDLADRELVVIIGW FhERRY IDAEN---SPYLHPQSGLPQKKTFEVDAVEN-KVVSLLLVAEPESILAMPDPTVPESDIKALITLCDLADRELVVNIGW HSERRY IDAEN----SPYLNPQLVQPAKKPLLWSDPADNKIVSHLLVAEPEKIYAMPDPTVPDSDIKALTTLCDLADRELVVIIGW

FhERR $\alpha$ HsERR $\alpha$ EhERRßa FhERRßb HSERR $\beta$ FhERRy HsERRY

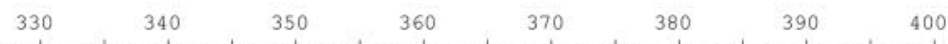
$\ldots \ldots|\ldots| \ldots|\ldots| \ldots|\ldots| \ldots|\ldots| \ldots|\ldots| \ldots|\ldots| \ldots|\ldots| \ldots|\ldots| \ldots|\ldots| \ldots \mid$ AKSI PGFSSLSLSDQMSVLQSVWMEVLVLGVAQRSLPLQDELAFAEDLVLDEEGARAAGLGELGAALLQLVRRLQALRLE AKHI PGFSTLSLADQMSLLQSAWMEI LVLS IVFRSLPCEDEIVYAEDYVVDEEQARISGLPDIHVAILPLVRRYKKLRME AKHI PGFSTLSLGDQMSLLQSAWMEILILSIVERSLPYEDELVYAEDYTMDEEHSRLT GLLDLYVSILQLVRKYKKLKVE AKHI PGFSSLSLGDQMSLLQSAWMEI L ILGIVYRSLPYDDKLVYAEDY IMDEEHSRLAGLLELYRAILQLVRRYKKLKVE AKHI PGFPTLSLADQMSLLOSGWMEI IILRVVFRSTMEDKLVYAEDYTMDEEOSKLAGLFDLNNAILQLVKKYKSMGLE AKHIPGFSTLSLADQMSLLQSAVMEILILGVVYRSLSFEDELVYADDYIMDEDQSKLAGLLDLNNAILQLVKKYKSMKLE

\begin{tabular}{|rrrrrrr}
410 & 420 & 430 & 440 & 450 & 460 & 470
\end{tabular}

FhERR $\alpha$

HSERR $\alpha$ $\ldots|\ldots| \ldots|\ldots| \ldots|\ldots| \ldots|\ldots| \ldots|\ldots| \ldots|\ldots \ldots| \ldots|\ldots| \ldots|\ldots| \ldots|\ldots| \ldots|\ldots|$ REEFVMLKAIALTNSDSVYIEDMEAVQKLRDLLHQGLLELECQRR-PD--DËQRAGRLLTLPLLRQTAGRALLTPEYSI REEYVLLKALALANSDSVHIEDAEAVEQLREALHEALLEYEAGRAGPGGGAERRRAGRLLLTLPLLRQTAGKVLAHFYGV KEEFVTLKAIALANSDSMHIESI BAVQRLQDSLHEALQDYEGSQHPED----PRRAGKLLMTLPLLRQTATKAVQHEYSI KEEFVTLKAIALANSDSMHIEDMEAVQKLQDALHEALQDYESSQHQED----PRRAGKLLMTLPLLRQTATKAVQHFYSI KEEFVTLKALALANSDSMYIEDLEAVQKLQDLLHEALQDYELSQRHEE----PWRTGKLLLTLPLLRQTAAKAVQHFYSV KEEFVLLKAIALANSDSMQIEDSEAVQRLQDVLHGALQDYEAAHHPED----CRRAGKLIMTLPLLRQTAARAVQHECSI KEEFVTLKAIALANSDSMHIEDVEAVQKLQDVLHEALODYEAGQHMED----PRRAGKMLMTLPLLRQTSTKAVQHFYNI

$\ldots \ldots|\ldots| \ldots|\ldots| \ldots$

FHERR $\alpha$ KTRGGVPMHKLFLEMLEAMMDSP

KLERR KOKVPMHKLFLEMLEAMMD

FHERRBb KVQGKVPMHKLFLEMLEAKV

HSERR $\beta$ KLQGKVPMHKLFLEMLEAKA

FhERRY KQDGRVPMHKLFLELLEAKV

HSERRY KLEGKVPMHKLFLEMLEAKV

Figure 1 Alignment of $F$. heteroclitus ERR amino acid sequences. Deduced amino acid sequences of four ERR genes cloned from $F$. heteroclitus were aligned with three human ERR genes using ClustalW within Bioedit. Identical residues are shaded. Sixteen amino acid residues shown in boldface indicate a portion of the $\operatorname{FhERR} \alpha$ sequence that was obtained from a separate PCR product. See Results for further information. The start codon of FhERR $\beta b$ is not known; three potential translation initiation sites are underlined. The DBD (C domain) is enclosed in brackets, and the start of the LBD (E/F domain) is indicated by an arrow. All GenBank accession numbers are given in Table 2. 
Table 2 ERR gene names, synonyms, and accession numbers. Ensembl predicted proteins from the following databases: human $31 \cdot 35 \mathrm{~d}$, Takifugu build 2c, release $31 \cdot 2 \mathrm{f}$, Tetraodon version 7, Danio release $31 \cdot 4 \mathrm{~d}$. Other Ensembl predicted proteins are abbreviated names and correspond to older assemblies for comparison with previously published literature (i.e. Bertrand et al. 2004)

\begin{tabular}{|c|c|c|c|c|c|}
\hline & Official name & Trivial name(s) & $\begin{array}{l}\text { Pubmed accession } \\
\text { number (protein) }\end{array}$ & $\begin{array}{l}\text { Ensembl predicted } \\
\text { protein }\end{array}$ & $\begin{array}{l}\text { 'Other’ Ensembl } \\
\text { predicted protein }\end{array}$ \\
\hline \multicolumn{6}{|l|}{ Species } \\
\hline \multirow[t]{3}{*}{ Human } & NR3B1 & $\mathrm{ERR} \alpha$, ESRRA & NP_004442 & ENSP00000000442 & \\
\hline & NR3B2 & $\begin{array}{l}\text { ERR } \beta \text {, ESRRB, } \\
\text { ERR2, ESRL2 }\end{array}$ & NP_004443 & ENSP00000261532 & \\
\hline & NR3B3 & ERR $\gamma$, ERR3 & NP_001429 & ENSP00000354584 & \\
\hline \multirow[t]{6}{*}{ Takifugu } & & $\mathrm{ERR} \alpha$ & $\mathrm{N} / \mathrm{A}^{-}$ & $\begin{array}{l}\text { SINFRUP } \\
00000138848\end{array}$ & SIN67383 \\
\hline & & ERRßa & $\mathrm{N} / \mathrm{A}$ & $\begin{array}{l}\text { SINFRUP } \\
00000140232\end{array}$ & SIN72315 \\
\hline & & $E R R \beta b$ & $\mathrm{~N} / \mathrm{A}$ & $\begin{array}{l}\text { SINFRUP } \\
00000141263\end{array}$ & FRUP141263/62880 \\
\hline & & ERRya & $\mathrm{N} / \mathrm{A}$ & $\begin{array}{l}\text { SINFRUP } \\
00000162788\end{array}$ & SIN57192 \\
\hline & & $\operatorname{ERR} \gamma b(\beta / \gamma)$ & $\mathrm{N} / \mathrm{A}$ & $\begin{array}{l}\text { SINFRUP } \\
00000130211\end{array}$ & $\begin{array}{l}\text { FRUP } \\
130211(51057)\end{array}$ \\
\hline & & ERR $\delta$ & $\mathrm{N} / \mathrm{A}$ & $\begin{array}{l}\text { SINFRUP } \\
00000134462\end{array}$ & FRUP134462 \\
\hline \multirow[t]{4}{*}{ Tetraodon } & & $\operatorname{ERR} \alpha$ & $\mathrm{N} / \mathrm{A}$ & $\begin{array}{l}\text { GSTENP } \\
00020389001\end{array}$ & GST20389 \\
\hline & & ERR $\beta a$ & $\mathrm{~N} / \mathrm{A}$ & $\begin{array}{l}\text { GSTENP } \\
00032328001\end{array}$ & GST32328 \\
\hline & & ERRra & $\mathrm{N} / \mathrm{A}$ & $\begin{array}{l}\text { GSTENP } \\
00032849001\end{array}$ & GST32848 \\
\hline & & $\operatorname{ERR} \gamma b(\beta / \gamma)$ & $\mathrm{N} / \mathrm{A}$ & $\begin{array}{l}\text { GSTENP } \\
00030242001\end{array}$ & FS563 \\
\hline \multirow[t]{5}{*}{ Danio } & & $\mathrm{ERR} \alpha$, esrral (zfin) & AAS66634 & $\begin{array}{l}\text { ENSDARP } \\
00000050433\end{array}$ & \\
\hline & & ERR $\beta b$ esrrb (zfin) & AAS66635 & $\begin{array}{l}\text { ENSDARP } \\
00000040417\end{array}$ & \\
\hline & & ERR $\gamma a$ esrrg (zfin) & AAS66636 & $\begin{array}{l}\text { ENSDARP } \\
00000005364\end{array}$ & \\
\hline & & $\begin{array}{l}\text { ERR } \gamma b, \text { ERR } \beta / \gamma \\
\text { esrrgl (zfin) }\end{array}$ & AAS66638 & $\begin{array}{l}\text { ENSDARP } \\
00000002838\end{array}$ & \\
\hline & & 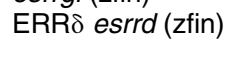 & AAS66637 & $\begin{array}{l}\text { ENSDARP } \\
00000013201\end{array}$ & \\
\hline \multirow[t]{4}{*}{ Fundulus } & & $\mathrm{ERR} \alpha$ & DQ241376 & $\mathrm{N} / \mathrm{A}$ & \\
\hline & & ERR $\beta a$ & DQ241377 & $\mathrm{N} / \mathrm{A}$ & \\
\hline & & ERR $\beta b$ & DQ241378 & $\mathrm{N} / \mathrm{A}$ & \\
\hline & & $\mathrm{ERR} \gamma \mathrm{b}(\beta / \gamma)$ & DQ241379 & $\mathrm{N} / \mathrm{A}$ & \\
\hline Drosophila & & ERR & NP_729340 & CG7404 (flybase) & \\
\hline
\end{tabular}

PAUP*4.0b10 software (Swofford 2003). The D. melanogaster ERR was used as the outgroup. Trees were constructed with a heuristic search strategy, and branch swapping and tree-bisection reconnection were repeated to obtain bootstrapping values from 1000 replicates.

In an attempt to further resolve the $\operatorname{ERR} \beta$ and ERR $\gamma$ clades, a second alignment was created using fish and mammalian $E R R \alpha, E R R \beta$, and $E R R \gamma$ sequences (i.e., no $\mathrm{ERR} \delta$ or invertebrate ERR sequences). Phylogenetic trees were created using parsimony and minimum evolution criteria, as previously, using $E R R \alpha$ genes as the outgroup. In addition, a maximum likelihood tree was constructed using Phylip 3.64 (Felsenstein 2004). Weights corresponding to 1000 bootstrap replicates were generated by SEQBOOT (within Phylip), and a $\gamma$-law parameter, $\alpha$, was estimated by PHYML (Guindon et al. 2005). Maximum likelihood trees were constructed using the Jones, Taylor and Thornton (JTT) substitution model (Jones et al. 1992) as implemented in ProML (within Phylip) with a $\gamma$ distribution of rates between sites (four categories). Consensus trees were created by CONSENSE and rooted with the ERR $\alpha$ sequences. Alternative tree topologies were compared with the maximum likelihood consensus tree using the Shimodaira-Hasegawa test (SH-test; Shimodaira \& Hasegawa 1999), as implemented in ProML. 


\section{Nomenclature}

We have named teleost co-orthologs (e.g. FhERR $\beta a$ and FhERR $\beta b$ ) to be consistent with zebrafish nomenclature rules (Sprague et al. 2001). Similar nomenclature has been applied to duplicated teleost ER genes (Hawkins \& Thomas 2004).

\section{Quantitative real-time RT-PCR (qPCR)}

F. heteroclitus ERR splice sites were predicted by comparing genomic sequences for human, fugu, and zebrafish ERRs with cDNA sequences (human, zebrafish) or gene predictions (fugu). Splice sites were generally well conserved among species and among various ERR genes within a species (data not shown). Primers for ERR $\alpha, E R R \beta a, E R R \beta b, E R R \gamma b$, and $\beta$-actin (Table 1) were designed with one primer spanning a predicted exon-exon junction to avoid amplification of genomic DNA. Primers for EF-1 (Bears et al. 2006) and vitellogenin (Garcio-Reyero et al. 2004) were taken from published studies. cDNA was synthesized from $2 \mu \mathrm{g}$ total RNA using random hexamers and the Omniscript cDNA Synthesis Kit (Qiagen). In the tissue-distribution study, cDNA was diluted in a ratio of $1: 3$ in ERR $\beta b$ and EF-1 assays. qPCR was performed using the iQ SYBR Green Supermix (Bio-Rad) and reactions were run in an iCycler iQ Real-Time PCR Detection System (BioRad). The PCR mixture consisted of the following: $11 \mu \mathrm{l}$ molecular biology grade distilled water, $12 \cdot 5 \mu \mathrm{l} \mathrm{Q}$ SYBR Green Supermix, $0 \cdot 25 \mu \mathrm{l} 5^{\prime}$-primer $(10 \mu \mathrm{M})$, $0 \cdot 25 \mu \mathrm{l} 5^{\prime}$-primer $(10 \mu \mathrm{M})$, and $1 \mu \mathrm{l} \mathrm{cDNA}$.

In the analysis of tissue distribution of ERRs, the PCR conditions for FhERR $\alpha$ and FhERR $\beta b$ were: $95{ }^{\circ} \mathrm{C} / 3 \mathrm{~min}, 95^{\circ} \mathrm{C} / 15 \mathrm{~s}, 66^{\circ} \mathrm{C} / 1 \mathrm{~min}, 40$ cycles. PCR conditions of other genes were identical except that annealing/extension temperatures were adjusted to maximize the amplification of the specific product: FhERRßa $\left(64^{\circ} \mathrm{C}\right)$, FhERR $\gamma \mathrm{b}\left(67 \cdot 9^{\circ} \mathrm{C}\right)$, EF-1 $\left(60^{\circ} \mathrm{C}\right)$. At the end of each PCR cycle, the PCR products were subjected to melt-curve analysis to ensure that only a single product was amplified. For both males and females, each of the nine tissues was represented by a single cDNA derived from pooled total RNA from three fish. There were three technical replicates (qPCR well) per sample per gene. Expression data were quantified based on threshold cycle $\left(C_{\mathrm{t}}\right)$ values and the $-2^{\Delta \Delta C_{\mathrm{t}}}$ method (Livak \& Schittgen, 2001). $\beta$-Actin expression was highly variable among tissues (data not shown), so for each ERR gene, $C_{\mathrm{t}}$ values were normalized to EF-1 (Bears et al. 2006). Relative mRNA expression for each gene was calculated as the fold change compared with the tissue with the lowest $C_{\mathrm{t}}$ (i.e. data were normalized such that the tissue with the highest expression was set equal to one).
For analysis of qPCR data from dosing experiments, a standard curve for each ERR gene was generated by serially diluting plasmids containing a full-length copy of each gene from $10^{3}$ to $10^{8}$ molecules/ $\mu$ l. The PCR conditions for FhERR $\alpha$, FhERR $\gamma b$, and Fh- $\beta$-actin were: $95^{\circ} \mathrm{C} / 3 \mathrm{~min}, 95^{\circ} \mathrm{C} / 15 \mathrm{~s}, 66^{\circ} \mathrm{C} / 1 \mathrm{~min}, 40$ cycles. PCR conditions for FhERR $\beta b$ were nearly identical: $95^{\circ} \mathrm{C} / 3 \mathrm{~min}, 95^{\circ} \mathrm{C} / 15 \mathrm{~s}, 64^{\circ} \mathrm{C} / 1 \mathrm{~min}, 40$ cycles. At the end of each PCR cycle, the PCR products were subjected to melt-curve analysis to ensure that only a single product was amplified. The number of molecules/ $\mu$ l for each gene of interest in each RNA sample was calculated from the standard curve. ERR expression was presented as unnormalized, and the $\beta$-actin expression is shown for comparison. The data were transformed via the natural logarithm to obtain a normal distribution (Shapiro-Wilk test and visual inspection of normal probability plots) and equality of variance (visual inspection of residuals) for each gene. Gene expression in estradiol-treated and control tissues were compared using two-tailed $t$-tests.

\section{Results}

\section{Cloning and phylogenetic analysis of killifish ERRs}

Using RT-PCR and 5'/3' RACE, full-length cDNA and deduced amino acid sequences were determined for four ERR genes in F. heteroclitus (Fig. 1).

Identical $441 \mathrm{bp}$ fragments of one ERR cDNA (FhERR $\alpha$ ) were cloned initially from total RNA derived from killifish liver, brain, kidney, and heart. The fulllength ERR $\alpha$ cDNA sequence is $1617 \mathrm{bp}$ in length, including $131 \mathrm{bp} 5^{\prime}$ untranslated sequence, an open reading frame of $1302 \mathrm{bp}$, and $185 \mathrm{bp} 3^{\prime}$ untranslated sequence including a poly-A + tail. The predicted amino acid sequence encodes a polypeptide 415 amino acid residues in length with a predicted molecular mass of $45 \cdot 8 \mathrm{kDa}$. Phylogenetic analysis using distance (minimum evolution, Fig. 2) or parsimony (not shown) criteria clearly indicate that FhERR $\alpha$ is closely related to $E R R \alpha$ genes found in mammals and other species of fish.

Each of the mammalian and teleost species included in this study contains a single ERR $\alpha$ gene. In contrast, the teleost ERR $\beta$ genes form two clades, which together are a sister group to the mammalian ERR $\beta$ genes (Bertrand et al. 2004, Fig. 2). We have identified two ERR $\beta$ genes in $F$. heteroclitus (FhERR $\beta$ a and FhERR $\beta b$ ); these genes are apparent co-orthologs of the mammalian ERR $\beta$ genes. Fragments (429 bp) of FhERR $\beta$ a cDNA were cloned from killifish brain and heart total RNA, and the full-length cDNA was cloned from brain poly-A+ RNA. The sequence is $1656 \mathrm{bp}$ long, including $185 \mathrm{bp}$ of $5^{\prime}$ untranslated sequence, an open reading frame of $1305 \mathrm{bp}$, and $166 \mathrm{bp} 3^{\prime}$ untranslated sequence. Available sequence for the $3^{\prime}$ UTR lacks a poly-A + tail 


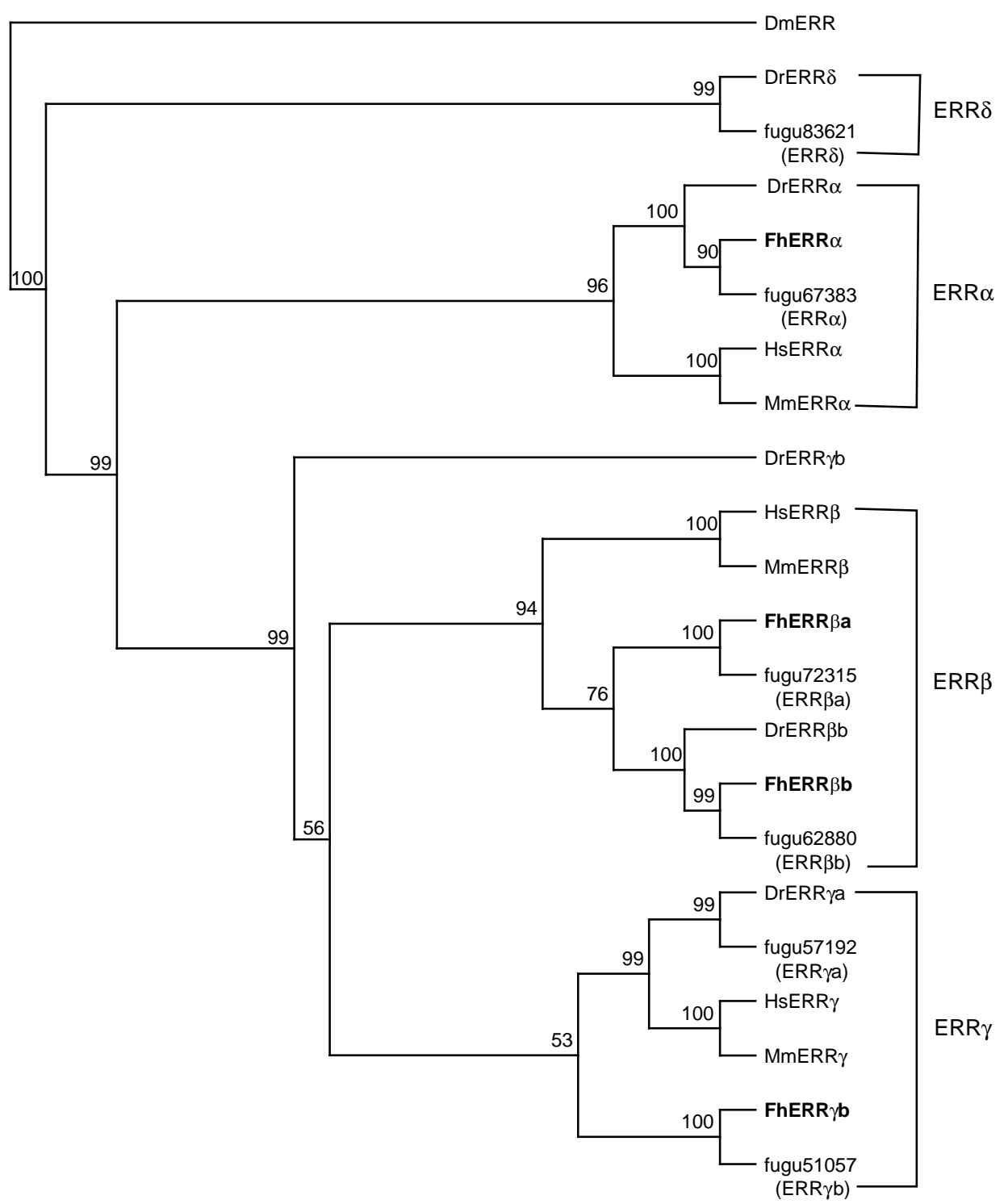

Figure 2 Phylogenetic analysis (minimum evolution) of ERR-predicted proteins. Deduced amino acid sequences of $F$. heteroclitus ERR genes (bold) were aligned with ERRs from fugu, zebrafish, human, mouse, and fruitfly using ClustalX 1.81. The A/B domains and gaps were excluded from analysis, and the distance criterion (minimum evolution) was used to produce a consensus tree with the $D$. melanogaster ERR as the designated outgroup. Bootstrapping values from 1000 replicates are shown. GenBank accession numbers are given in Table 2.

and may be incomplete. The predicted amino acid sequence encodes a polypeptide, 435 amino acid residues in length, with a predicted molecular mass of $48 \cdot 2 \mathrm{kDa}$. FhERR $\beta$ a is most closely related to a predicted protein in fugu (fugu72315, Fig. 2).

A 499 bp fragment of FhERRßb cDNA was cloned from killifish eye total RNA. The putative complete cDNA sequence (1634 bp) was obtained using brain total RNA. The translated sequence contains three methionine residues near the $5^{\prime}$ end. The predicted proteins corresponding to these potential start codons are 443,447 , and 477 amino acid residues in length, with $176 \mathrm{bp}$ of $3^{\prime}$ UTR. Thus, the predicted molecular mass ranges from $48 \cdot 5$ to $53 \cdot 6 \mathrm{kDa}$. Both distance and parsimony analyses indicate that FhERR $\beta b$ is most closely related to an ERR $\beta$ cDNA cloned from zebrafish (Bardet $e$ al. 2004) and to a predicted protein in fugu (fugu62880, Fig. 2). 
A $324 \mathrm{bp}$ fragment of a fourth ERR cDNA, FhERR $\gamma \mathrm{b}$ was cloned from killifish heart cDNA. The cDNA sequence corresponding to the complete coding region was obtained by RACE and PCR with gene-specific primers using brain total RNA. The sequence includes $132 \mathrm{bp}$ of $5^{\prime}$ UTR, $1320 \mathrm{bp}$ coding region, and a partial $3^{\prime}$ UTR of $88 \mathrm{bp}$. The predicted protein contains 439 amino acid residues and the predicted molecular mass is $48 \cdot 3 \mathrm{kDa}$. Phylogenetic analysis using distance criterion (minimum evolution) indicates that FhERR $\gamma \mathrm{b}$ is a form of ERR $\gamma$ and an ortholog of a predicted protein in fugu (fugu51057, Fig. 2), but inclusion of FhERR $\gamma b$ and fugu51057 in the ERR $\gamma$ clade has a relatively low bootstrap support (Fig. 2). Parsimonybased analysis of the same alignment indicates that these two fish ERRs form a sister group to the ERR $\beta$ and ERR $\gamma$ clades (not shown), as described for zebrafish (Bardet et al. 2004).

To further investigate the evolutionary relationships, we aligned the full-length vertebrate $\operatorname{ERR} \alpha, \operatorname{ERR} \beta$, and ERR $\gamma$ sequences and constructed phylogenetic trees with distance, parsimony, and maximum likelihood criteria (Fig. 3). As in the previous analysis, placement of FhERR $\gamma \mathrm{b}$, fugu51057, and DrERR $\gamma \mathrm{b}$ were equivocal. The parsimony-based analysis placed the three genes within the ERR $\gamma$ clade (with bootstrap support of $54 \%$ ), but there were polytomies within the clade. The distance tree placed all the three genes as sister to the ERR $\beta$ and ERR $\gamma$ clades, in contrast to the previous distance analysis (which included ERR $\delta$ s and the ERR from D. melanogaster Fig. 2), which placed the fish genes within the ERR $\gamma$ clade. The maximum likelihood consensus tree was consistent with a fishspecific duplication of $\mathrm{ERR} \gamma$, with low bootstrap support (Fig. 3), which is similar to the results from a previous study (Bertrand et al. 2004). However, an SH-test showed that the topology indicated by the maximum likelihood tree was not significantly better than two alternative topologies: (1) FhERR $\gamma b$, fugu51057, and DrERR $\gamma$ b grouping outside the clade formed by mammalian ERRs and teleost ERR $\gamma$ a genes (SH-test, $P=0 \cdot 45$ ) and (2) DrERR $\gamma \mathrm{b}$ grouping outside the other fish and mammalian ERR $\gamma \mathrm{s}(P=0 \cdot 155)$. The maximum likelihood tree was also unable to resolve the branching patterns within the ERR $\beta$ clade.

Possible explanations for the 'outgroup topology' (i.e. fish ERR genes grouping outside the ERR $\beta$ and ERR $\gamma$ clades) include an ancient duplication, or artifacts due to differences in evolutionary rate or saturation (Van de Peer et al. 2003). We used the program AsaturA (Van de Peer et al. 2002) with a range of cut-off values, substitution matrices, and distance correction methods to explore the effects of amino acid saturation on the topology of trees made with distance and parsimony criteria. In no case did the tree topology provide clear evidence for two groups of fish ERR $\gamma$ co-orthologs of mammalian ERR $\gamma$ genes, as would be expected if fish ERR $\gamma$ diversity resulted from a duplication in the teleost lineage. The results from these parsimony- and distance-based analyses contradict both the predictions from a teleost genome duplication and the weakly supported results from maximum likelihood analysis. Thus, the evolutionary history of FhERR $\gamma \mathrm{b}$ and related genes in fugu and zebrafish remains unresolved. We have provisionally named FhERR $\gamma b$ based on the hypothesis that this gene resulted from a teleostspecific duplication of an ancestral ERR $\gamma$, as suggested by Bertrand et al. (2004).

\section{Tissue-specific expression}

FhERR $\alpha$, FhERR $\beta a$, FhERR $\beta b$, and FhERR $\gamma b$ transcripts were measured by qPCR in tissues from male and female fish. F. heteroclitus ERR genes showed distinct, partially overlapping expression patterns (Fig. 4). FhERR $\alpha$ was widely expressed and detectable in all tissues studied. FhERR $\beta$ a was expressed at low levels in brain, female eye, and ovary. FhERR $\beta$ b was detected primarily in gonad, eye, brain, and male liver, whereas FhERR $\gamma$ b was detected primarily in kidney, eye, heart, and gill. Males and females showed some differences in ERR expression including the ovarian, but not testicular, expression of ERR $\beta$ a. Since each tissue was represented by a single pooled sample, a more detailed study is needed to determine the sexspecific expression patterns.

\section{Effects of estradiol exposure on ERR expression}

In the first experiment, male fish were injected with estradiol, or a vehicle control, and transcript expression of ERR $\alpha$, ERR $\beta b$, and $E R R \gamma b$ was quantified in several tissues using qPCR (Fig. 5). Two days after exposure, expression of ERR $\alpha, E R R \beta b$, and ERR $\gamma \mathrm{b}$ was not significantly affected by estradiol dosage for any tissue $(P>0 \cdot 05)$, although there was a high degree of variability among the samples. In particular, 2 days after injection, a single fish displayed relatively high levels of ERR $\alpha$ expression in heart, testis, and gill. Because the same fish showed elevated $\beta$-actin expression in some tissues, statistical analysis was repeated on unnormalized data, but this did not result in any significant differences. The greatest trend toward induction was observed for $\mathrm{ERR} \alpha$ expression in heart tissue. In comparing the mean transcript levels, FhERR $\alpha$ expression was 2.6-fold higher in $\mathrm{E}_{2}$-treated normalized heart tissues relative to the control. The fish with the highest ERR $\alpha$ expression had transcript levels $5 \cdot 3$-fold greater than the control mean transcript level. A power 


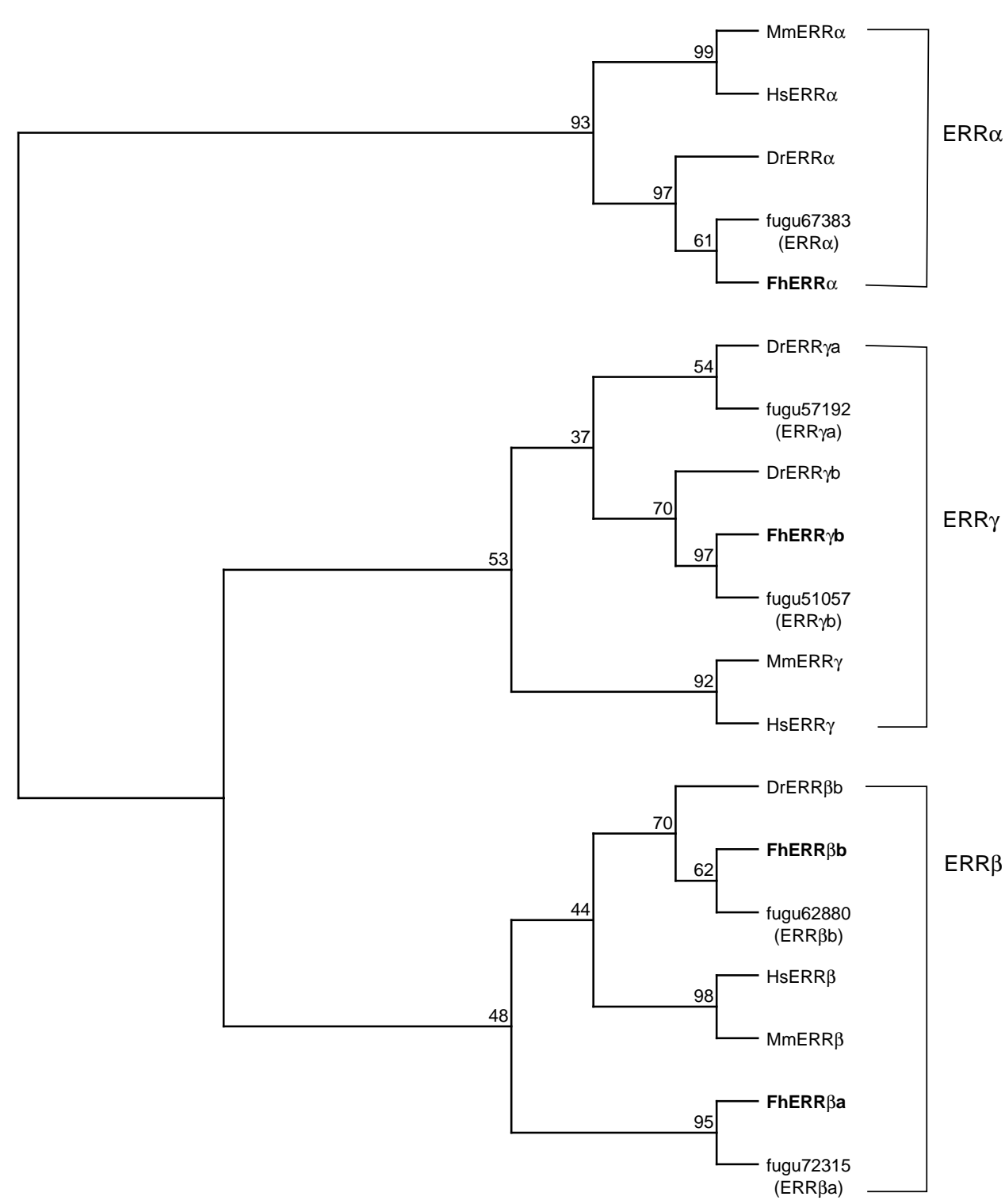

Figure 3 Maximum likelihood analysis of ERR $\alpha$-, ERR $\beta$-, and ERR $\gamma$-predicted proteins. Deduced amino acid sequences of $F$. heteroclitus ERR genes (bold) were aligned with ERRs from fugu, zebrafish, human, and mouse using ClustalX 1.81. The A/B domains and gaps were excluded from analysis, and maximum likelihood criterion was used to produce a consensus tree that was rooted with the ERR $\alpha$ sequences. Bootstrapping values from 1000 replicates are shown. GenBank accession numbers are given in Table 2.

analysis demonstrated that to detect a threefold induction in FhERR $\alpha$ expression in heart $(\alpha=0 \cdot 05$, $1-\beta=0 \cdot 80)$, a sample size of 12 fish per treatment would have been needed. In the experiment conducted in this study $(n=3)$, a 15 -fold induction would have been detected with a power of $0.874(\alpha=0.05)$. Thus, the high inter-individual variability of ERR expression precludes the detection of modest differences in expression. We also measured FhERR $\alpha$ and $\beta$-actin expression in fish 5 days after exposure to $\mathrm{E}_{2}$ or a vehicle control. We detected no effect of $\mathrm{E}_{2}$ exposure on FhERR $\alpha$ expression in these fish (data not shown). In a related study using qPCR with the same tissues, we have detected a twofold induction of cytochrome P450 aromatase B (AroB) expression in brain and greater than 100-fold induction of vitellogenin in the liver (SR Greytak, AM Tarrant, ME Hahn \& GV Gallard, unpublished observations). Induction of AroB and vitellogenin by estradiol demonstrates that the fish were effectively exposed and normally responsive to estradiol. 
A
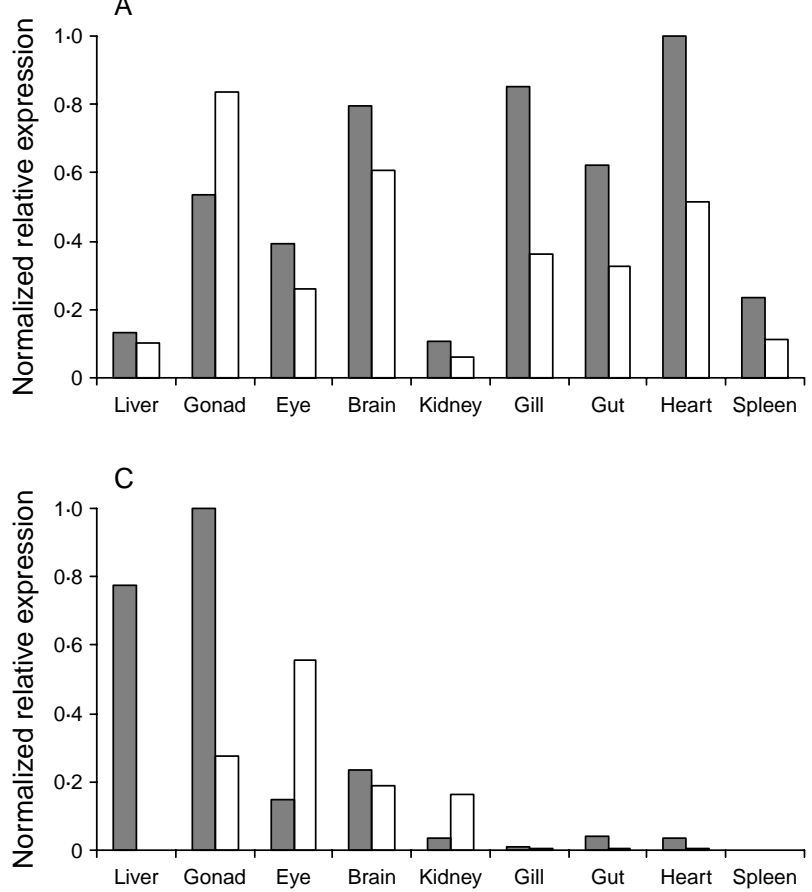

B

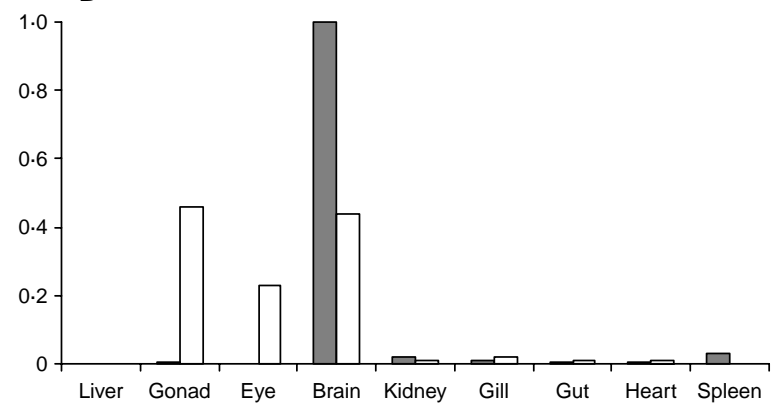

D

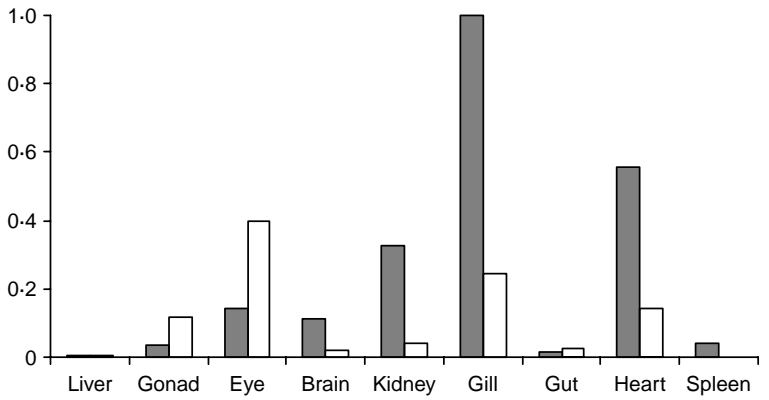

Figure 4 Tissue-specific expression of $F$. heteroclitus ERRs. Relative expression of four $F$. heteroclitus ERRs ((A) ERR $\alpha,(B)$ ERR $\beta a$, (C) ERR $\beta b$, (D) ERR $\gamma$ b) was measured in cDNAs from adult male (shaded bars) and female fish (open bars) by qPCR, as described in Materials and methods. Expression of each ERR gene was normalized to EF-1. Relative mRNA expression for each tissue is represented as the fold change relative to the expression in the highest-expressing tissue (thus setting maximum relative expression equal to one). For each sex, relative expression was calculated from the mean of three technical replicates from a single cDNA pool derived from three fish.

In a second more targeted experiment, ERR $\alpha$ transcript expression was quantified in the hearts from female fish injected with estradiol or a vehicle control (Fig. 6). Two days after exposure, expression of $\mathrm{ERR} \alpha$ was downregulated $2 \cdot 5$-fold in heart relative to the control $(P=0 \cdot 001)$. Liver from a subset of these fish showed a greater than 100 -fold induction of vitellogenin (data not shown), demonstrating the effectiveness of the estrogen exposure.

\section{Discussion}

\section{ERR diversity in F. heteroclitus}

Examination of genomic databases and cloning efforts have demonstrated that teleost fish have additional diversity of ERR genes relative to mammals (Maglich et al. 2003, Bardet et al. 2004, Bertrand et al. 2004, this study). Increased diversity of nuclear receptors and other genes has been attributed to frequent gene duplication or to a genome duplication within the teleost lineage (Robinson-Rechavi et al. 2001a,b, Taylor et al. 2003). In zebrafish, the five ERR genes are each on separate chromosomes, as predicted from version 4 of the genome assembly. (In version 5 of the assembly, the zebrafish ERR $\beta$ is on a scaffold that has not been mapped to a chromosome.) In tetraodon, two genes (GSTENG00030324001, an ortholog of FhERRßa, and GSTENG00030242001, an ortholog of FhERR $\gamma$ b) are both on chromosome 14, but they are separated by approximately $800 \mathrm{~kb}$. Thus, the additional ERR diversity observed in teleosts cannot be explained by recent tandem duplication events.

In the present study, we have identified four ERR genes from $F$. heteroclitus. These genes are predicted to be orthologs of four of the six ERR genes predicted from the fugu genome. Without a fully sequenced genome, it is not possible to know whether we have identified the full complement of ERR genes in F. heteroclitus. In our cloning efforts, we did not identify orthologs of ERR $\gamma \mathrm{a}$ or ERR $\delta$ genes, which are present in pufferfish genomes and expressed in zebrafish embryos (Bardet et al. 2004, Bertrand et al. 2004). These genes may have been lost from $F$. heteroclitus or may have been difficult to detect, possibly due to the low expression in the adult tissues examined. Among the four killifish ERRs we identified, FhERR $\alpha$ is an ortholog of the single ERR $\alpha$ identified in mammals, pufferfish, and zebrafish. FhERRßa and 

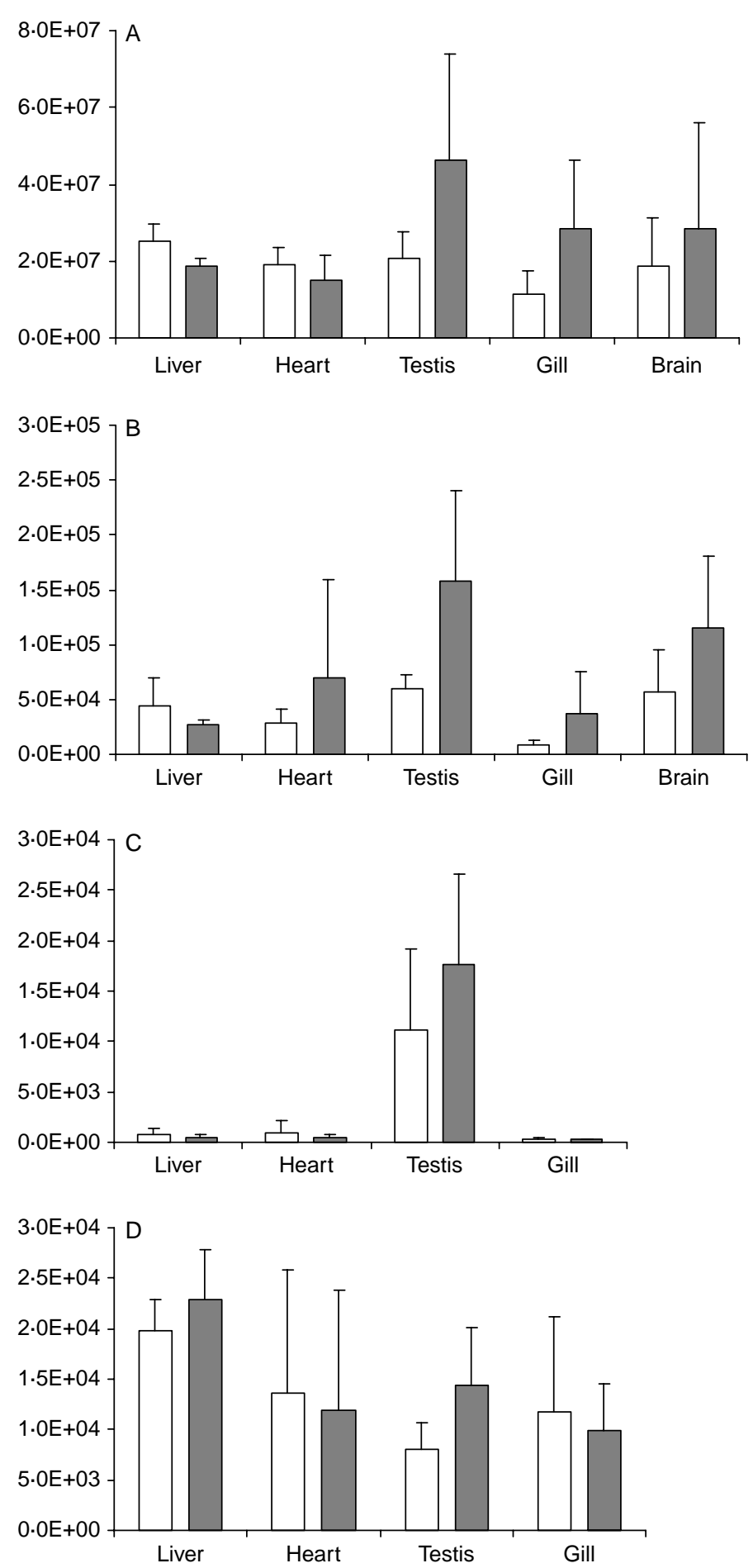

Figure 5 Effects of estradiol treatment on ERR expression in $F$. heteroclitus males. Adult male $F$. heteroclitus were injected intra-peritoneally with a vehicle control (open bars) or with $5 \mu \mathrm{g} / \mathrm{g}$ body weight $\mathrm{E}_{2}$ (shaded bars) and sacrificed after 2 days. Tissue-specific expression of: $\beta$-actin $(A), E R R \alpha(B)$, ERR $\beta b(C)$, and ERR $\gamma b(D)$ was measured by qPCR. Error bars represent S.D. $\left(n=3\right.$ fish). No significant effects $(\alpha=0.05)$ of $E_{2}$ treatment were detected (see the text for further details). 

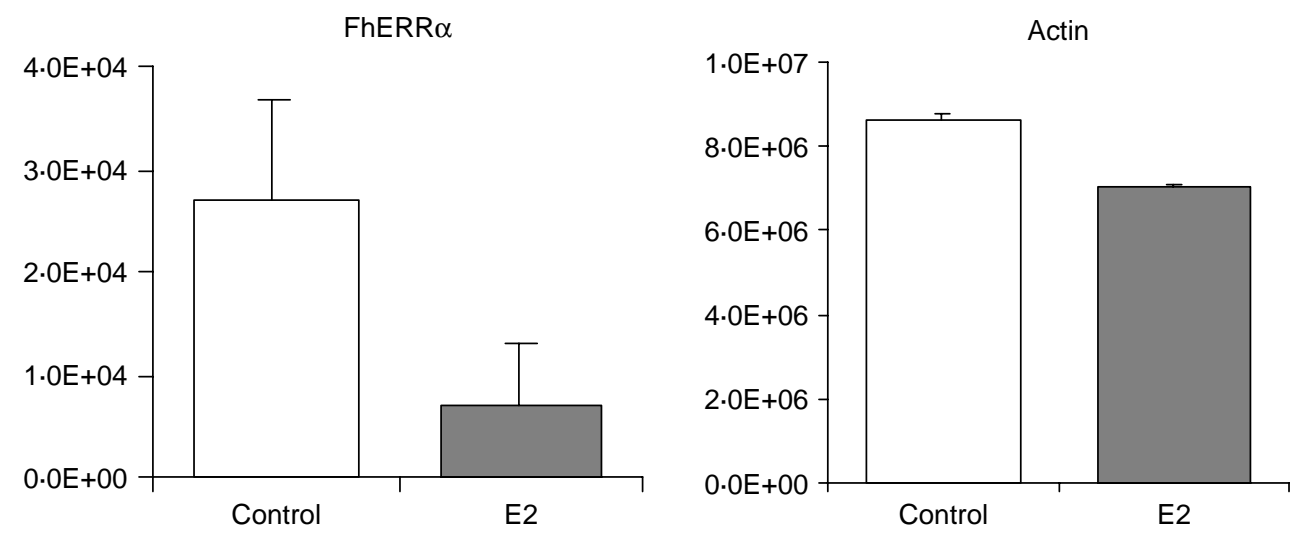

Figure 6 Effects of estradiol treatment on ERR $\alpha$ expression in $F$. heteroclitus female heart. Adult female $F$. heteroclitus were injected intra-peritoneally with a vehicle control (open bars) or with $5 \mu \mathrm{g} / \mathrm{g}$ body weight $E_{2}$ (shaded bars) and sacrificed after 2 days. Expression of ERR $\alpha$ and $\beta$-actin was measured by qPCR. Error bars represent S.D. ( $n=12$ estradiol treatment, $n=13$ vehicle control). ERR $\alpha$ expression was $2 \cdot 5$-fold lower in estradiol-treated fish relative to fish injected with a vehicle control $(P=0.001$; see the text for further details).

FhERR $\beta b$ are co-orthologs of the mammalian ERR $\beta$, as indicated by parsimony and distance analysis. Similarly, duplicated ERR $\beta$ genes have been identified in the fugu, tetraodon, and medaka genomes (Bertrand et al. 2004, AM Tarrant, unpublished data). In contrast, only a single ERR $\beta$, similar to FhERR $\beta b$, is present in the zebrafish (Bardet et al. 2004); however, the tree topology is consistent with the loss of an ERRßa-like gene from the zebrafish lineage.

The phylogenetic placement of FhERR $\gamma b$ is less clear. Fugu and zebrafish each have one gene that groups clearly as an ERR $\gamma$ and a second gene that groups as an ERR $\gamma$ or within a sister group to the ERR $\beta$ and ERR $\gamma$ clades, depending on the analysis. Our likelihood analysis and a previously published likelihood analysis (Bertrand et al. 2004) are consistent with the hypothesis that there has been a duplication of ERR $\gamma$ within the teleost lineage. However, bootstrap support for the grouping of two fish ERR $\gamma$ genes is low in both analyses. We have tentatively identified these groups of fish genes as ERR $\gamma$ a and ERR $\gamma b$. FhERR $\gamma b$ is an apparent ortholog of this second group of fish genes.

Translation of the FhERR $\beta$ b cDNA sequence revealed three methionine residues near the $\mathrm{N}$-terminus of the predicted protein, and it is not clear which of these residues represents the translation initiation site(s). The third methionine aligns with the predicted start site of most other ERRs, including HsERR $\beta$ and FhERR $\beta \mathrm{a}$, and this methionine has an adenine at the -3 position, the most conserved position in the Kozak consensus sequence (Kozak 1987). We did not detect multiple potential start codons of FhERR $\beta a$, and similarly did not detect multiple potential start codons in genomic sequences corresponding to other fish ERR $\beta$ genes. The predicted ERR $\beta$ sequence for the chimpanzee (GenBank accession number XP510082) similarly has an additional methionine upstream of the predicted start site for most ERR $\beta$ genes, and the sequence near the $\mathrm{N}$ terminus is highly similar to FhERRßa. It is possible that multiple initiation sites are used for some ERR $\beta$ genes. Indeed, apparent isoforms of HsERR $\gamma$ that use different initiation sites have been described based on cDNA sequences obtained from different tissues (Heard et al. 2000). Further, application of several specific antibodies revealed that mammalian glucocorticoid-receptor mRNAs produce multiple functional isoforms that differ primarily in the $\mathrm{N}$-termini and have distinct expression patterns and functional properties ( $\mathrm{Lu} \&$ Cidlowski 2005). The biological significance of multiple predicted start sites within the FhERRßb sequence is currently unknown.

\section{Tissue-specific expression}

This study contains the first description of spatial patterns of ERR-transcript expression in adult fish. Like its mammalian ortholog, FhERR $\alpha$ was broadly expressed and detectable in all tissues. FhERRßa was apparently expressed at low levels in the eye, brain, and ovary. FhERR $\beta b$ was detected primarily in the liver, gonad, eye, brain, and kidney, and FhERR $\gamma \mathrm{b}$ in the eye, kidney, gill, and heart. While expression patterns were similar between males and females, some differences are apparent, such as expression of ERR $\beta \mathrm{a}$ in female eye and ovary. In the initial tissue comparison, the tissues from male and female fish are each represented by a single cDNA, and therefore, a more detailed analysis with multiple independent samples throughout the reproductive cycle will be needed to robustly compare expression patterns. 
The ERR expression patterns indicate the utility of $F$. heteroclitus and other fish models for the characterization of ERR function in future. For example, FhERR $\beta a$ and FhERR $\beta b$ have distinct spatial expression patterns, which may indicate subfunctionalization of the co-orthologs. Thus, $F$. heteroclitus may serve as a particularly useful model for dissecting the ERR $\beta$ function. Mammalian ERR $\beta$ helps regulate placental development and primordial germ cell proliferation. Expression of FhERRßa in ovary is particularly interesting in this respect and is consistent with some role of ERR $\beta$ in killifish reproduction. The role of ERR $\beta$ in teleost development is unknown and would also be interesting to study, particularly given the differences in extraembryonic tissues between fishes and mammals. To give a second example, ERR $\gamma$ function remains poorly characterized in any organism, and mouse knockout phenotypes have not been described. The additional diversity of ERR $\gamma$-like genes in teleosts, such as zebrafish, may facilitate characterization of function through knockdown experiments. In addition, FhERR $\gamma b$ expression in gill might indicate unique function relative to mammalian ERRs.

\section{Effects of estradiol dosage on ERR expression}

In the first experiment, we detected no significant effects of exposure to $E_{2}(5 \mu \mathrm{g} / \mathrm{g}$ body weight) on ERR gene expression in any tissue. We did observe substantial variability among individual fishes and a trend towards a slight induction (three- to five-fold) of $\mathrm{ERR} \alpha$ expression in heart. In a more targeted experiment with female fish, we observed a highly significant 2-5-fold downregulation of ERR $\alpha$ expression in heart following estrogen exposure. This downregulation contrasts with reports of $\mathrm{ERR} \alpha$ induction by estrogens in some mammalian tissues (Shigeta et al. 1997, Liu et al. 2003).

The effect of estrogen exposure on mammalian ERR $\alpha$ expression is primarily mediated through multiple steroid hormone-response element half-sites that are conserved between the human and mouse ERR $\alpha$ gene promoters (Liu et al. 2003). While fish ERR gene promoters have not yet been characterized fully, in preliminary searches of teleost genomic databases, we have not identified any of the predicted ER response elements upstream of fish ERR genes (data not shown). Downregulation of $\mathrm{ERR} \alpha$ in female heart following exposure to estradiol may indicate an important difference in regulation of expression between teleosts and mammals. This difference warrants further investigation and may provide an opportunity to identify estrogen-independent pathways of ERR expression. For example, ERR $\alpha$ expression in some mouse tissues displays circadian rhythmicity (Horard et al. 2004).
In conclusion, we have identified four ERR genes in F. heteroclitus. Phylogenetic analysis of our sequences and other teleost ERRs indicates that fishes possess additional diversity of ERRs relative to mammals and specifically that $F$. heteroclitus contains co-orthologs of ERR $\beta$. Further, characterization of the duplicated genes may provide insight into conserved or teleost-specific functions of ERR $\beta$. Downregulation of ERR $\alpha$ in the female heart by estradiol in our study also suggests that ERR expression is regulated differently in fishes and mammals.

\section{Acknowledgements}

We thank Ann Michelle Morrison for F. heteroclitus RNA samples used to measure tissue-specific expression. Sibel Karchner, Diana Franks, and Brad Evans assisted with the development of qPCR assays. Jed Goldstone, Rob Jennings, and Ken Halanych provided advice on maximum likelihood analysis.

\section{Funding}

This research was supported by the National Institutes of Health under Ruth L Kirschstein National Research Service Award (F32 ES013092-01) from the National Institute of Environmental Health Sciences, the Seward Johnson Foundation and the Superfund Basic Research Program (P42ES007381). The authors declare that there is no conflict of interest that would prejudice the impartiality of this work.

\section{References}

Amores A, Force A, Yan Y, Joly L, Amemiya C, Fritz A, Ho R, Langeland J, Prince V, Wang Y et al. 1998 Zebrafish hox clusters and vertebrate genome evolution. Science 282 1711-1714.

Bardet P-L, Horard B, Robinson-Rechavi M, Laudet V \& Vanacker J-M 2002 Characterization of oestrogen receptors in zebrafish (Danio rerio). Journal of Molecular Endocrinology 28 153-163.

Bardet P-L, Obrect-Pflumio S, Thisse C, Laudet V, Thisse B \& Vanacker J-M 2004 Cloning and developmental expression of five estrogen-receptor related genes in the zebrafish. Development Genes and Evolution 214 240-249.

Bardet P-L, Horard B, Laudet V \& Vanacker J-M $2005 a$ The ERR $\alpha$ orphan nuclear receptor controls morphogenetic movements during zebrafish gastrulation. Developmental Biology 281 102-111.

Bardet P-L, Schubert M, Horard B, Holland L, Laudet V, Holland N \& Vanacker J-M $2005 b$ Expression of estrogen-receptor related receptors in amphioxus and zebrafish: implications for the evolution of posterior brain segmentation at the invertebrateto-vertebrate transition. Evolution and Development 7 223-233.

Bears H, Richards J \& Schulte P 2006 Arsenic exposure alters hepatic arsenic species composition and stress-mediated gene expression in the common killifish (Fundulus heteroclitus). Aquatic Toxicology 77 257-266. 
Bertrand S, Brunet F, Escriva H, Parmentier G, Laudet V \& Robinson-Rechavi M 2004 Evolutionary genomics of nuclear receptors: from twenty-five ancestral genes to derived endocrine systems. Molecular Biology and Evolution 21 1923-1937.

Bonnelye E, Vanacker J, Spruyt N, Alric S, Fournier B, Desbiens X \& Laudet V $1997 a$ Expression of the estrogen-related receptor 1 (ERR-1) orphan receptor during mouse development. Mechanisms of Development 65 71-85.

Bonnelye E, Vanacker J, Dittmar T, Begue A, Desbiens X, Denhardt D, Aubin J, Laudet V \& Fournier B $1997 b$ The ERR-1 orphan receptor is a transcriptional activator expressed during bone development. Molecular Endocrinology 11 905-916.

Bonnelye E, Merdad L, Kung V \& Aubin J 2001 The orphan nuclear estrogen receptor-related receptor $\alpha(\mathrm{ERR} \alpha)$ is expressed throughout osteoblast differentiation and regulates bone formation in vitro. Journal of Cell Biology 153 971-983.

Boudreau M, Courtenay S, MacLatchy D, Berube C, Parrott J \& Van der Kraak G 2004 Utility of morphological abnormalities during earlylife development of the estuarine mummichog, Fundulus heteroclitus as an indicator of estrogenic and antiestrogenic endocrine disruption. Environmental Toxicology and Chemistry 23 415-425.

Carletta M, Weis P \& Weis J 2002 Development of thyroid abnormalities in mummichogs, Fundulus heteroclitus, from a polluted site. Marine Environmental Research 54 601-604.

Chen F, Zhang Q, McDonald T, Davidoff M, Bailey W, Bai C, Liu Q \& Caskey C 1999 Identification of two hERR2-related novel nuclear receptors utlizing bioinformatics and inverse PCR. Gene 228 101-109.

Christoffels A, Koh E, Chia J, Brenner S, Aparicio S \& Venkatesh B 2004 Fugu genome analysis provides evidence for a whole-genome duplication early during the evolution of ray-finned fishes. Molecular Biology and Evolution 21 1146-1151.

Coward P, Lee D, Hull MV \& Lehmann JM 2001 4-Hydroxytamoxifen binds to and deactivates the estrogen-related receptor $\gamma$. PNAS 98 $8880-8884$.

Dube M \& MacLatchy D 2001 Identification and treatment of a waste stream at a bleached-kraft pulp mill that depresses a sex steroid in the mummichog (Fundulus heteroclitus). Environmental Toxicology and Chemistry 20 985-995.

Felsenstein J 2004 PHYLIP (Phylogeny Inference Package) version 3.64, Department of Genome Sciences and Department of Biology, University of Washington, Seattle, WH (distributed by the author; http://evolution.genetics.washington.edu/phylip.html).

Force A, Lynch M, Pickett F, Amores A, Yan Y \& Postlethwait J 1999 Preservation of duplicate genes by complementary, degenerative mutations. Genetics 151 1531-1545.

Garcio-Reyero N, Raldua D, Quiros L, Llaveria G, Cerda J, Barcelo D, Grimalt J \& Pina B 2004 Use of vitellogenin mRNA as a biomarker for endocrine disruption in feral and cultured fish. Analytical and Bioanalytical Chemistry 378 670-675.

Giguere V 2002 To ERR in the estrogen pathway. Trends in Endocrinology and Metabolism 13 220-225.

Giguere V, Yang N, Segui P \& Evans R 1988 Identification of a new class of steroid hormone receptors. Nature 331 91-94.

Greschik H, Wurtz J-M, Sanglier S, Bourguet W, van Dorsselaer A, Moras D \& Renaud J-P 2002 Structural and functional evidence for ligand-independent transcriptional activation by the estrogenrelated receptor 3. Molecular Cell 9 303-313.

Greytak S, Champlin D \& Callard G 2005 Isolation and characterization of two cytochrome P450 aromatase forms in killifish (Fundulus heteroclitus): differential expression in fish from polluted and unpolluted environments. Aquatic Toxicology 71 371-389.

Guindon S, Lethiec F, Duroux P \& Gascuel O 2005 PHYML Online-a web server for fast maximum likelihood-based phylogenetic inference. Nucleic Acids Research 33 W557-W559.

Hall TA 1999 Bioedit: a user-friendly biological sequence alignment editor and analysis program for Windows 95/98/NT. Nucleic Acids Symposium Series 41 95-98.
Hawkins MB \& Thomas P 2004 The unusual binding properties of the third distinct teleost estrogen receptor subtype ERßa are accompanied by highly conserved amino acid changes in the ligand binding domain. Endocrinology 145 2968-2977.

Heard D, Norby P, Holloway J \& Vissing H 2000 Human ERR $\gamma$, a third member of the estrogen receptor-related receptor (ERR) subfamily of orphan nuclear receptors: tissue-specific isoforms are expressed during development and in the adult. Molecular Endocrinology 14 382-392.

Hermans-Borgmeyer I, Susens U \& Borgmeyer U 2000 Developmental expression of the estrogen receptor-related receptor $\gamma$ in the nervous system during mouse embryogenesis. Mechanisms of Development 97 197-199.

Hewitt L, Smyth S, Dube M, Gilman C \& MacLatchy D 2002 Isolation of compounds from bleached kraft mill recovery condensates associated with reduced levels of testosterone in mummichog (Fundulus heteroclitus). Environmental Toxicology and Chemistry 21 $1359-1367$.

Hong H, Yang L \& Stallcup M 1999 Hormone-independent transcriptional activation and coactivator binding by novel orphan receptor ERR3. Journal of Biological Chemistry 274 22618-22626.

Horard B, Rayet B, Triqueneaux G, Laudet V, Delaunay F \& Vanacker J-M 2004 Expression of the orphan nuclear receptor $E R R \alpha$ is under circadian regulation in estrogen-responsive tissues. Journal of Molecular Endocrinology 33 87-97.

Ichida M, Nemoto S \& Finkel T 2002 Identification of a specific molecular repressor of the nuclear coactivator PGC-1 $\alpha$. Journal of Biological Chemistry 277 50991-50995.

Jaillon O, Aury J-M, Brunet F, Petit J-L, Stange-Thomann N, Mauceli E, Bouneau L, Fischer C, Ozouf-Costaz C, Bernot A et al. 2004 Genome duplication in the teleost fish Tetraodon nigroviridis reveals the early vertebrate proto-karyotype. Nature 431 946-957.

Jones DT, Taylor WR \& Thornton JM 1992 The rapid generation of mutation data matrices from protein sequences. Computer Applications in the Biosciences 8 275-282.

Kozak M 1987 An analysis of 5'-noncoding sequences from 699 vertebrate messenger RNAs. Nucleic Acids Research 25 8125-8148.

Liu D, Zhang Z, Gladwell W \& Teng C 2003 Estrogen stimulates estrogen-related receptor alpha gene expression through conserved hormone response elements. Endocrinology 144 4894-4904.

Livak KJ \& Schittgen TD 2001 Analysis of relative gene expression data using real-time quantitative PCR and the 2(-DDC(T)) method. Methods 25 402-408.

Lu N \& Cidlowski J 2005 Translational regulatory mechanisms generate $\mathrm{N}$-terminal glucocorticoid receptor isoforms with unique transcriptional target genes. Molecular Cell 18 331-342.

Luo J, Sladek R, Bader J-A, Matthyssen A, Rossant J \& Giguere V 1997 Placental abnormalities in mouse embryos lacking the orphan nuclear receptor ERR- $\beta$. Nature 388 778-782.

Luo J, Sladek R, Carrier J, Bader J-A, Richard D \& Giguere V 2003 Reduced fat mass in mice lacking orphan nuclear receptor estrogenrelated receptor $\alpha$. Molecular and Cellular Biology 23 7947-7956.

Lynch M \& Force A 2000 The probability of duplicate gene preservation by subfunctionalization. Genetics 154 459-473.

MacLatchy D, Courtenay S, Rice C \& Van der Kraak G 2003 Development of a short-term reproductive endocrine bioassay using steroid hormone and vitellogenin end points in the estuarine mummichog (Fundulus heteroclitus). Environmental Toxicology and Chemistry 22 996-1008.

Maglich J, Caravella J, Lambert M, Willson T, Moore J \& Ramamurthy L 2003 The first completed genome sequence from a teleost fish (Fugu rubripes) adds significant diversity to the nuclear receptor superfamily. Nucleic Acids Research 31 4051-4058.

Mitsunaga K, Araki K, Mizusaki J, Morohashi K-I, Haruna K, Nakagata N, Giguere V, Yamamura K-I \& Abe K 2004 Loss of PGC-specific expression of the orphan nuclear receptor ERR- $\beta$ results in reduction of germ cell number in mouse embryos. Mechanisms of Development 121 237-246. 
Pait A \& Nelson J 2003 Vitellogenesis in male Fundulus heteroclitus (killifish) induced by selected estrogenic compounds. Aquatic Toxicology 64 331-342.

Pankhurst N, Stacey N \& Peter R 1985 An evaluation of techniques for the administration of $17 \beta$-estradiol to teleosts. Aquaculture $\mathbf{5 2}$ $145-155$.

Pettersson K, Svensson K, Mattsson R, Carlsson B, Ohlsson R \& Berkenstam A 1996 Expression of a novel member of estrogen response element-binding nuclear receptors is restricted to the early stages of chorion formation during mouse embryogenesis. Mechanisms of Development 54 211-223.

Postlethwait J, Amores A, Cresko W, Singer A \& Yan Y 2004 Subfunction partitioning, the teleost radiation and the annotation of the human genome. Trends in Genetics 20 481-490.

Robinson-Rechavi M, Marchand O, Escriva H \& Laudet V $2001 a$ An ancestral whole-genome duplication may not have been responsible for the abundance of duplicated fish genes. Current Biology 11 R458-R459.

Robinson-Rechavi M, Marchand O, Escriva H, Bardet P-L, Zelus D, Hughes S \& Laudet V $2001 b$ Euteleost fish genomes are characterized by expansion of gene families. Genome Research 11 781-788.

Sanyal S, Kim J-Y, Kim H-J, Takeda J, Lee Y-K, Moore D \& Choi H-S 2002 Differential regulation of the orphan nuclear receptor small heterodimer partner (SHP) gene promoter by orphan nuclear receptor ERR isoforms. Journal of Biological Chemistry 277 1739-1748.

Seely J, Amigh K, Suzuki T, Mayhew B, Sasano H, Giguere V, Laganiere J, Carr B \& Rainey W 2005 Transcriptional regulation of dehydroepiandrosterone sulfotransferase (SULT2A1) by estrogen-related receptor $\alpha(\mathrm{ERR} \alpha)$. Endocrinology 146 3605-3613.

Shi H, Shigeta H, Yang N, Fu K, O'Brian G \& Teng C 1997 Human estrogen receptor-like 1 (ESRL1) gene: genomic organization, chromosomal localization, and promoter characterization. Genomics 44 52-60.

Shigeta H, Zuo W, Yang N, DiAugustine R \& Teng C 1997 The mouse estrogen receptor-related orphan receptor alpha 1 : molecular cloning and estrogen responsiveness. Journal of Molecular Endocrinology 19 299-309.

Shimodaira H \& Hasegawa M 1999 Multiple comparisons of loglikelihoods with applications to phylogenetic inference. Molecular Biology and Evolution 16 1114-1116.

Sprague J, Doerry E, Douglas S, Westerfield M \& Group TZ 2001 The zebrafish information network (ZFIN): a resource for genetic, genomic and developmental research. Nucleic Acids Research 29 87-90.

Sumi D \& Ignarro L 2003 Estrogen-related receptor $\alpha 1$ up-regulates endothelial nitric oxide synthase expression. PNAS 100 14451-14456.

Swofford D 2003 PAUP*: Phylogenetic Analysis Using Parsimony (and Other Methods). Version 4.0b8. Sinauer Associates, Sunderland, MA.

Taylor J, Van de Peer Y, Braasch I \& Meyer A 2001 Comparative genomics provides evidence for an ancient genome duplication event in fish. Philosophical Transactions of the Royal Society B Biological Sciences 356 1661-1679.
Taylor J, Braasch I, Frickey T, Meyer A \& Van de Peer Y 2003 Genome duplication, a trait shared by 22,000 species of ray-finned fish. Genome Research 13 382-390.

Tremblay G, Bergeron D \& Giguere V $2001 a$ 4-Hydroxytamoxifen is an isoform-specific inhibitor of orphan estrogen-receptor-related (ERR) nuclear receptors $\beta$ and $\gamma$. Endocrinology 142 4572-4575.

Tremblay G, Kunath T, Bergeron D, Lapointe L, Champigny C, Bader J-A, Rossant J \& Giguere V $2001 b$ Diethystilbestrol regulates trophoblast stem cell differentiation as a ligand of orphan nuclear receptor ERR $\beta$. Genes and Development 15 833-835.

Van de Peer Y, Frickey T, Taylor JS \& Meyer A 2002 Dealing with saturation at the amino acid level: a case study based on anciently duplicated zebrafish genes. Gene 295 205-211.

Van de Peer Y, Taylor JS \& Meyer A 2003 Are all fishes ancient polyploids? Journal of Structural and Functional Genomics 2 65-73.

Vanacker J-M, Bonnelye E, Delmarre C \& Laudet V 1998 Activation of the thyroid hormone receptor $\alpha$ gene promoter by the orphan nuclear receptor ERR $\alpha$. Oncogene 17 2429-2435.

Vanacker J-M, Pettersson K, Gustafsson J-A \& Laudet V 1999 a Transcriptional targets shared by estrogen receptor-related receptors (ERRs) and estrogen receptor (ER) $\alpha$, but not by ER $\beta$. EMBO Journal 18 4270-4279.

Vanacker J-M, Petterson K, Gustafsson J-A \& Laudet V $1999 b$ Transcriptional activities of the orphan nuclear receptor ERR alpha (estrogen receptor-related receptor-alpha). Molecular Endocrinology 13 764-773.

Xie W, Hong H, Yang N, Lin R, Simon C, Stalcup M \& Evans R 1999 Constitutive activation of transcription and binding of coactivator by estrogen-related receptors 1 and 2. Molecular and Cellular Endocrinology 13 1594-1604.

Yang C, Shigeta H, Shi H \& Teng C 1996 Estrogen-related receptor, hERR1, modulates estrogen receptor-mediated response of human lactoferrin gene promoter. Journal of Biological Chemistry 271 $5795-5804$.

Yang C, Zhou D \& Chen S 1998 Modulation of aromatase expression in the breast tissue by ERR $\alpha-1$ orphan receptor. Cancer Research $\mathbf{5 8}$ $5695-5700$.

Zhang Z \& Teng C 2000 Estrogen receptor-related receptor- $\alpha 1$ interacts with coactivator and constitutively activates the estrogen response elements of the human lactoferrin gene. Journal of Biological Chemistry 275 20837-20846.

Zhou T, John-Alder H, Weis J \& Weis P 2000 Endocrine disruption: thyroid dysfunction in mummichogs (Fundulus heteroclitus) from a polluted habitat. Marine Environmental Research 50 393-397.

Received in final form 1 May 2006

Accepted 8 May 2006

Made available online as an Accepted Preprint 9 May 2006 